\title{
Rare Earth Elements in the Water Column of Sungai Balok, Pahang, Malaysia as Monsoon Event Proxies
}

\author{
Zolhizir Daud, Che Abd Rahim Mohamed* \\ Department of Earth Sciences \& Environment, Faculty of Science and Technology, Universiti Kebangsaan Malaysia, Bangi, \\ Selangor, Malaysia \\ Email: *carmohd@ukm.edu.my
}

How to cite this paper: Daud, Z. and Mohamed, C.A.R. (2020) Rare Earth Elements in the Water Column of Sungai Balok, Pahang, Malaysia as Monsoon Event Proxies. Journal of Environmental Protection, 11, 421-440.

https://doi.org/10.4236/jep.2020.115025

Received: March 22, 2020

Accepted: May 24, 2020

Published: May 27, 2020

Copyright $\odot 2020$ by author(s) and Scientific Research Publishing Inc. This work is licensed under the Creative Commons Attribution International License (CC BY 4.0).

http://creativecommons.org/licenses/by/4.0/

\begin{abstract}
Sampling of surface water at seven stations along the Sungai Balok, Pahang was conducted from 2013 to 2015 to investigate the distribution of dissolved rare earth elements (REE) in river systems. The whole concentration of $\Sigma$ REE in the dissolved phase recorded during this study ranged from 368 to 9121 $\mathrm{pmol} \cdot \mathrm{L}^{-1}$ with a mean of $2328 \pm 1442 \mathrm{pmol} \cdot \mathrm{L}^{-1}$ that was dominantly influenced by the concentration of Ce ranging from 84 to $3237 \mathrm{pmol} \cdot \mathrm{L}^{-1}$. Similarly, the large ranged value of $\mathrm{La} / \mathrm{Yb}_{\mathrm{N}}(0.69$ - 11.57) might be due to the fluctuating rainfall events during samplings as well as input from lithogenic sources that suggests the influence of monsoon events. The highly significant statistical correlation of $\mathrm{Al}$ and $\mathrm{Fe}\left(\mathrm{R}^{2}=0.65 ; p<0.01\right)$ also suggests the resuspension and mixing of REEs in the water column. However, the lower ratio of $\mathrm{Y} / \mathrm{Ho}<$ 55 might be due to the large volume of freshwater input especially during the Northeast monsoon (November to March). Therefore, the highest inventories of Ce were during $15^{\text {th }}$ January 2014 and $1^{\text {st }}$ November 2014 with 586.5 pmol. $\mathrm{cm}^{-2}$ and $643.4 \mathrm{pmol} \cdot \mathrm{cm}^{-2}$, accordingly. Subsequently, results showed an increasing flux of Ce occurring in the dissolved phase from November 2013 to January 2014 and November 2014 to January 2015, with 39.14 $\mathrm{nmol} \cdot \mathrm{cm}^{-2} \cdot \mathrm{yr}^{-1}$ and $59.78 \mathrm{nmol} \cdot \mathrm{cm}^{-2} \cdot \mathrm{yr}^{-1}$, respectively.
\end{abstract}

\section{Keywords}

Rainfall, Sediment, Water Column, Monsoon, Dissolved Phase

\section{Introduction}

Studies on distributions of dissolved REEs in river and marine environments were previously conducted based on river discharge loadings, rainfall and 
sources of geology such as granite and carbonatite [1]. The distribution of dissolved REEs in the marine environment is attributed to the affinity of water to dissolved minerals onto the particle surface [2]. Therefore, dissolved REEs in river systems are associated with monsoon events that were explained previously e.g. river discharge, geological input and rainfall distribution in the Chow Phraya River, Thailand and Mandovi River, India [3]. The abundance of REEs in the dissolved phase of tropical rivers usually corresponds to salinity, carbonate complex and biological processes [4].

The monsoon period of the southern South China Sea is always changing and not fixed every year. Therefore, this study is important to examine the presence of monsoon effects over sampling periods with the climatological data of wind flow direction and rainfall distribution. The distribution of REEs in dissolved phases had been observed in various environments such as global rivers [5], biogeochemical cycles in Tokyo Bay [6], granite sources [7], and most recently published in the Bay of Bengal by Yu et al. (2017) [8]. Dissolved REEs in rainwater have been discussed based more on industrial effects e.g., mining and atmospheric pollutants during wet deposition within acidic rainwater [9]. However, the rainfall aspect in tropical river systems and changing monsoons have not been well discussed by the previous researchers and in this study the authors have selected the Sungai Balok, Pahang, Malaysia as a pilot study area to elucidate REEs with rainfall events.

The upstream of Sungai Balok is in the hilly mountain near the granite belt [10] therefore, the river receives large amounts of dissolved and particulate loads due to heavy rainfall events especially during the Northeast monsoon. The increase in river discharge also brings higher terrestrial inputs as well as erodes the mangrove forest in the river system. The idea of establishing selected REE proxies i.e., $\mathrm{La} / \mathrm{Yb}$ and $\mathrm{Y} / \mathrm{Ho}$ was conducted previously in studies on dissolved REE in rainwater but overlooked the abundance of La compared Ce and the positive anomaly of Ce and Gd. This however, was not used to directly determine any REE proxies for studying the monsoon changes. Since $\mathrm{La} / \mathrm{Yb}_{\mathrm{N}}$ was used by Thompson et al. (2013) [11], and Takahashi and Noriki (2007) [6] in the estuaries of several major rivers around the world and in Tokyo Bay, respectively, it was deduced to have the potential to be the REE proxy in Sungai Balok for the determination of the monsoon due to rainfall seasonality [12]. The terrigenous detritus also contains lithogenic sources including organic and inorganic components through the weathering in estuarine environments. Meanwhile, previous studies on higher dissolved REE concentrations from lithogenic organic sources were investigated in Tokyo Bay [6] as well as Bay of Bengal [13]. Hence, the objective of this study is to investigate the distribution of REEs during various sampling periods and to determine the suitable proxy of lithogenic sources using a species of REEs.

\section{Sampling and Analytical Procedures}

Sungai Balok is located on the East coast Peninsular of Malaysia with water 
depths ranging from $0.5-6 \mathrm{~m}$, length is $\sim 5 \mathrm{~km}$ and the average width is $\sim 13.3 \mathrm{~m}$. The estuarine and river systems are surrounded by mangrove forests and undergo semi-diurnal tides. Surface water was collected using a clean water sampler at seven stations of the river during nine sampling trips from 2013 to 2015 (Table 1; Figure 1). In the laboratory, water samples were filtered immediately using $0.45 \mu \mathrm{m}$ membrane filter paper and acidified to $\mathrm{pH} 2$. The filtrate was in the dissolved form while the samples remaining on the filter paper were considered suspended particles samples. Dissolved samples were then stored in acid washed polyethylene bottle [7] with $50 \mathrm{ml}$ of $4 \% \mathrm{HNO}_{3}$ and kept in a cool box prior to further analysis in the laboratory. Water quality parameter i.e., salinity, was also recorded using the calibrated water quality multi-parameter AAQ-1183H manufactured by Alec Electronics Co. Ltd.

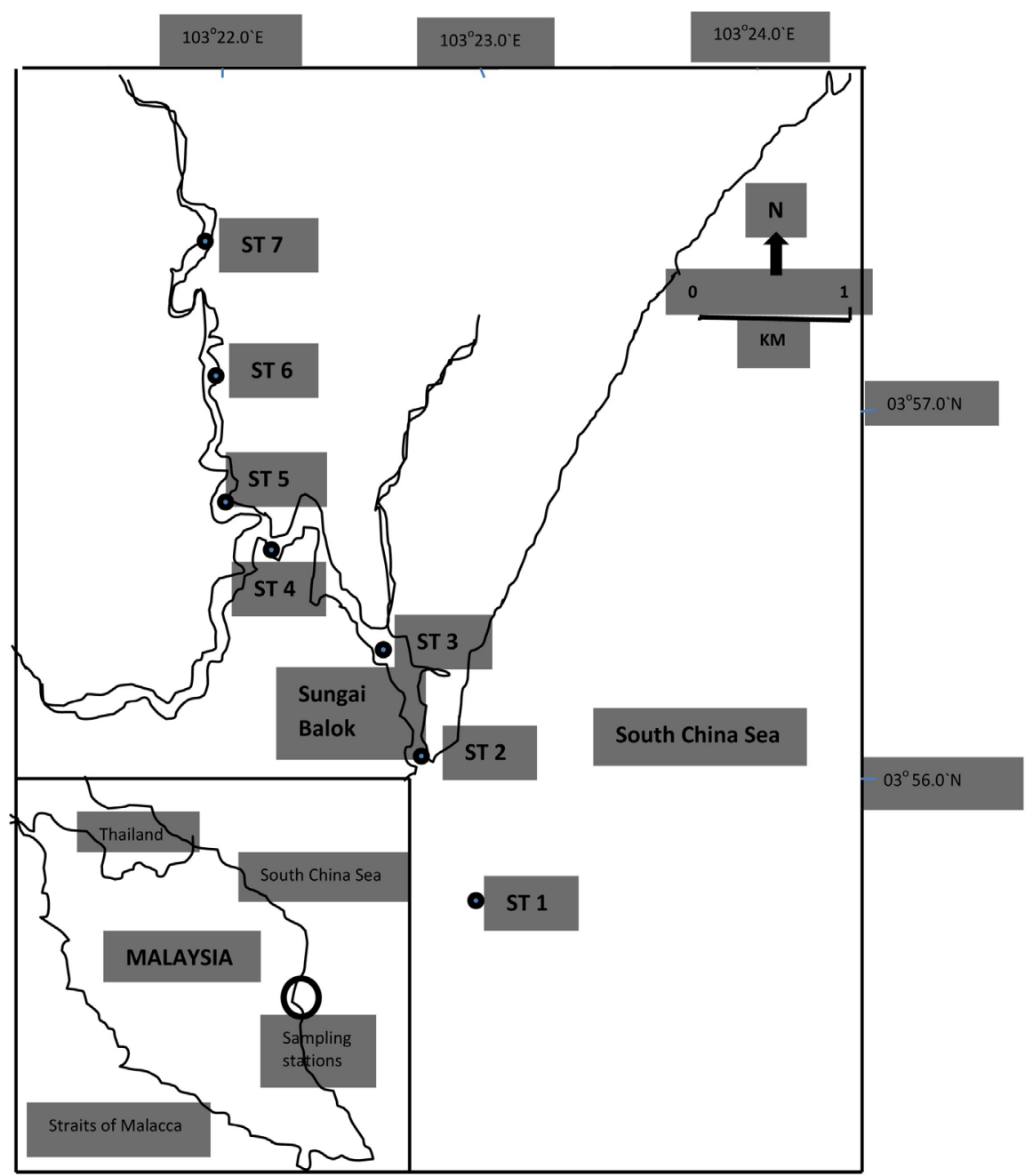

Figure 1. The map of location sampling of Sungai Balok also including the respectively depth with ST1 (6 m); ST2 (0.5 m); ST3 (1.5 m); ST4 (4 m); ST5 (5 m); ST6 (5 m) and ST7 $(4.8 \mathrm{~m})$. Sampling station also divided into three categories as coastal zone (ST1 and ST2), estuarine zone (ST3, ST4 and ST5) and river zone (ST6 and ST7). About nine times of sampling were conducted as 16-Jan-2013, 24-April-2013, 16-July-2013, 01-November-2013, 15-January-2014, 24-April-2014, 17-July-2014, 01-November-2014 and 31-January-2015. 
Table 1. GPS coordinates of sampling stations at the Sungai Balok.

\begin{tabular}{cccccc}
\hline \multirow{2}{*}{ Area } & \multirow{2}{*}{$\begin{array}{c}\text { Station } \\
\text { (ST) }\end{array}$} & \multicolumn{2}{c}{ GPS coordinates } & $\begin{array}{c}\text { Depth } \\
\text { (m) }\end{array}$ & Remarks \\
\cline { 3 - 6 } Coastal & 1 & $03^{\circ} 55.714^{\prime}$ & $103^{\circ} 22.884^{\prime}$ & 6 & Extension from river mouth \\
& 2 & $03^{\circ} 55.928^{\prime}$ & $103^{\circ} 22.652^{\prime}$ & 0.5 & Sand bar area \\
& 3 & $03^{\circ} 56.242^{\prime}$ & $103^{\circ} 22.443^{\prime}$ & 1.5 & Junction to Sungai Tungkak \\
Estuarine & 4 & $03^{\circ} 56.630^{\prime}$ & $103^{\circ} 22.086^{\prime}$ & 4 & Junction to Sungai Pengkalan Baru \\
& 5 & $03^{\circ} 56.780^{\prime}$ & $103^{\circ} 21.974^{\prime}$ & 5 & Mangrove and nymph forest \\
& 6 & $03^{\circ} 57.140^{\prime}$ & $103^{\circ} 21.800^{\prime}$ & 5 & Mangrove and nymph forest \\
\hline
\end{tabular}

The published analytical procedure was followed with the pre-concentration method using Chelex-100 resin [14]. While the trace elements such as $\mathrm{Al}, \mathrm{Mn}$ and Fe were also analyzed using the published protocol of Bourg (1983) [15]. The Standard Reference Material (SRM) was also prepared by spiking multi-REE elements $(10 \mathrm{ppm})$ and standard solution of trace elements (10 ppm) into artificial seawater and running them as actual samples to observe their recovery yield (90\% - 95\%). The concentration levels of biological silicate (Biogenic $\mathrm{SiO}_{2}$ ) were determined using the yellow silicomolybdate techniques Coradin et al., (2004) [16].

The results of REEs have been normalized with the Post Archean Australian Average Sedimentary rock or Shale (PAAS), which is the nearest continental crust for further discussion [7]. According to Daud and Mohamed (2016) [1], the geological setting of Sungai Balok is enriched with sedimentary rock or clay along basaltic rock, which is similar to PAAS. Generally the REEs members will divide into two groups as light rare earth element (LREE) which in the periodic table is from lanthanum ( $\mathrm{La}$ ) to Europium (Eu) and heavy rare earth element (HREE) is from gadolinium (Gd) to lutetium (Lu). Subsequently, the estimated flux of REE in Sungai Balok was calculated using the following published Equation (1) [17].

$$
\text { Flux }=\text { The sampling period }\left(\text { day } \cdot \mathrm{yr}^{-1}\right) \times 86400 \mathrm{~s} \cdot \mathrm{day}^{-1} \frac{1}{N} \sum_{i=1}^{N} c(t i) \times Q(t i)
$$

The ratio of $\frac{1}{N}$ is a conversion factor which is obtained from days of sampling period per year while 86,400 is the calculated seconds per day value. The $c(t i)$ is concentration of represented dissolved REE ( $\mathrm{pmol} \cdot \mathrm{L}^{-1}$ ) and $Q(t i)$ is the average daily river discharge in $\mathrm{L} \cdot \mathrm{s}^{-1} \cdot \mathrm{km}^{-2}$ or $\mathrm{m}^{3} \cdot \mathrm{s}^{-1} \cdot \mathrm{km}^{-2}$. According to DID (2011) [18], the National water resources report has stated that Sungai Balok has similar category of a small tributary such as Sungai Lepar near the major river of Sungai Pahang with daily discharge of $\sim 4.59 \mathrm{~m}^{3} \cdot \mathrm{s}^{-1}$ or $4.59 \times 10^{3} \mathrm{~L} \cdot \mathrm{s}^{-1}$ while the size of the river area is $\sim 66.5 \times 10^{-3} \mathrm{~km}^{2}$. The statistical analysis used was the correlation matrix and ANOVA using SPSS version 21 to determine a significant cor- 
relation and differences of selected total dissolved REE concentrations, the REE proxy ratios and some essential elements where statistically significant and different when $p \leq 0.05$ or 0.01 .

\section{Results and Discussions}

\subsection{Rare Earth Element in Dissolved Phase}

The distribution of dissolved REEs varies from upstream to downstream especially during November and January. During this period, the total dissolved rare earth elements ( $\Sigma$ REEs) ranged from 368 to $9121 \mathrm{pmol} \cdot \mathrm{L}^{-1}$, with a mean value of $2328 \pm 1442 \mathrm{pmol} \cdot \mathrm{L}^{-1}$, and LREE/HREE ratio ranging from $5.20 \pm 0.97$ to 22.41 \pm 3.00 (Table 2). The LREE concentrations along the sampling stations ranged from 344 to $8724 \mathrm{pmol} \cdot \mathrm{L}^{-1}$ and HREE from 23.5 to $593 \mathrm{pmol} \cdot \mathrm{L}^{-1}$. According to McLennan (1989) [19] the abundance of total dissolved REEs strongly supports the huge concentration of Cerium (Ce). The concentrations of Ce also varied between 84 to $3237 \mathrm{pmol} \cdot \mathrm{L}^{-1}$ with the highest mean concentration of $1680 \pm 730$ pmol. $\mathrm{L}^{-1}$ recorded in November 2014 (Table 2). These results were probably due to the high rainfall events [14]. Dissolution of Ce in January 2014 was observed to be statistically higher due to the higher monthly rainfall distribution $(\mathrm{r}=$ 0.328; $p<0.05$ ) with $277 \mathrm{~mm}$ (Figure 2). The same results were obtained after the flooding disaster in December 2013 due to heavy rainfall $(>1800 \mathrm{~mm})$ as well as in November 2014 when the rainfall was about $288 \mathrm{~mm}$. Hence these incidents have increased the REE contents in the water column.

There were no significant differences and distributions of REE contents among the stations from upstream to downstream $(p>0.05)$ except between sampling periods $(p<0.05)$ because the depth of the water column is very shallow e.g., less than $5 \mathrm{~m}$ during high tide which might have caused active resuspension. According to Shynu et al. (2011) [3] the resuspension activities of dissolved REEs in rivers might be from surface sediment to water column as well as re-suspended in subsurface waters from the river runoff. The resuspension and mixing process of REEs in the water column was also observed based on the significant statistical correlation between $\mathrm{Al}$ and $\mathrm{Fe}\left(\mathrm{R}^{2}=0.65 ; p<0.01\right)$ that was discussed previously in Bourg (1983) [15]. Regarding the concentration of $\mathrm{Fe}$ and $\mathrm{Al}$ that showed opposite trends to concentration of dissolved REEs, the species in Table 2 might be desorbed from particles or resuspended from surface sediment. This may have been caused by active river discharge transportation from the upper stream after incorporation of heavy rainfall and sources from groundwater discharge [12].

The sampling sites were divided into three zones which were river, estuarine and coastal (Table 1; Figures 3(b)-(d)) to examine the dissolved REE concentrations based on the salinity gradient whereby $27-33$ psu, $13-<27$ psu and $<13$ psu represent coastal, estuary and river areas, respectively. The concentrations of $\Sigma$ REEs slightly decreases towards the estuarine zone (mean range: 514 - 3713 $\mathrm{pmol} \cdot \mathrm{L}^{-1}$ ) and increases in the coastal zone (mean range: 387 to $6087 \mathrm{pmol} \cdot \mathrm{L}^{-1}$ ). 
Table 2. Concentrations of selected dissolved REE (pmol. $\mathrm{L}^{-1}$ ) of $\mathrm{Y}, \mathrm{Ce}, \mathrm{Nd}$, Eu and Ho, LREE, HREE and Total REE, the ratios of $\mathrm{Ce} / \mathrm{Ce}^{\star}, \mathrm{Eu} / \mathrm{Eu}^{\star}, \mathrm{Y} / \mathrm{Ho}, \mathrm{La} / \mathrm{Yb}_{\mathrm{N}}$, and selected essential elements $\left(\mu \mathrm{mol} \cdot \mathrm{L}^{-1}\right)$ of $\mathrm{Fe}, \mathrm{Mn}$ and $\mathrm{Al}$ in Sungai Balok.

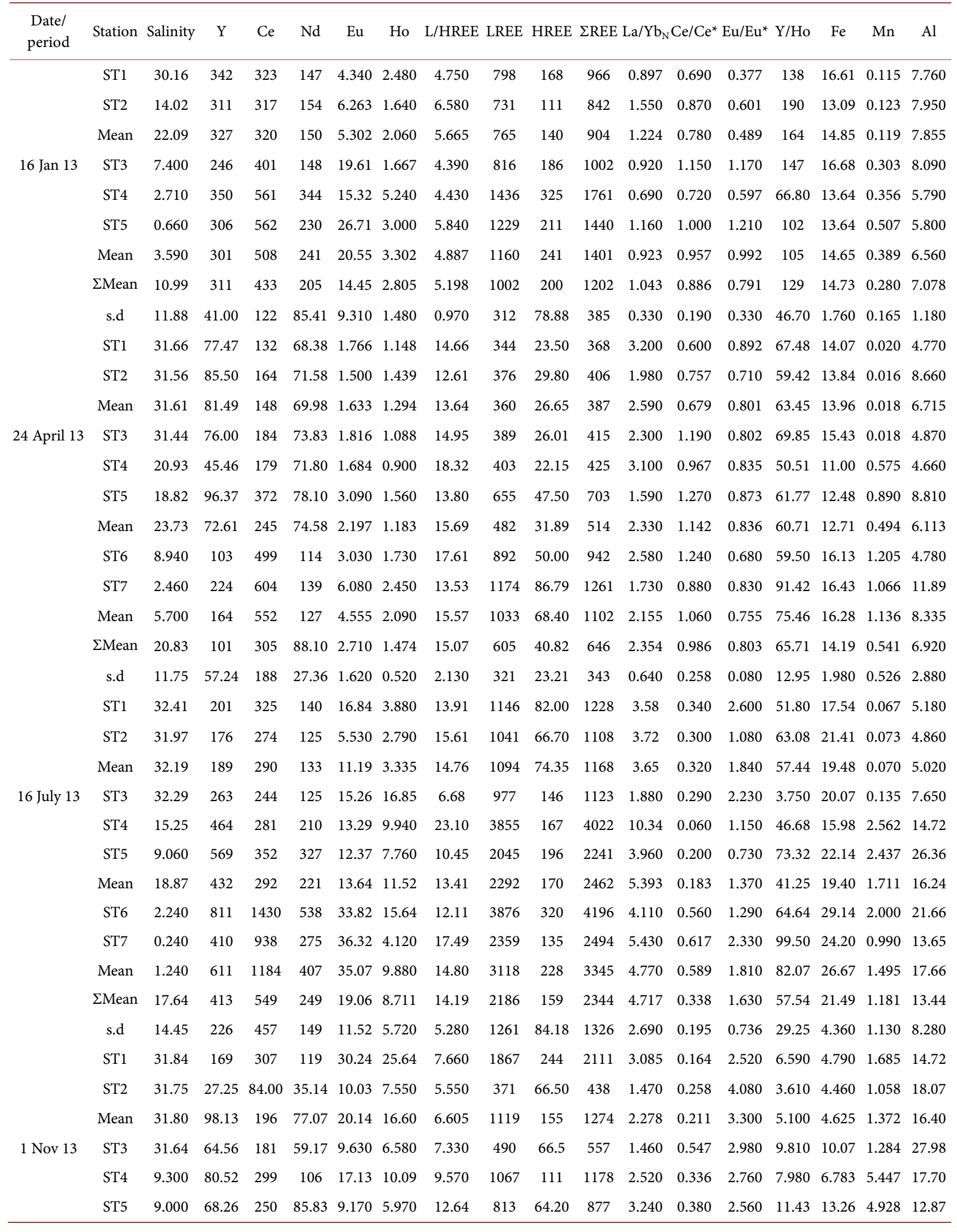




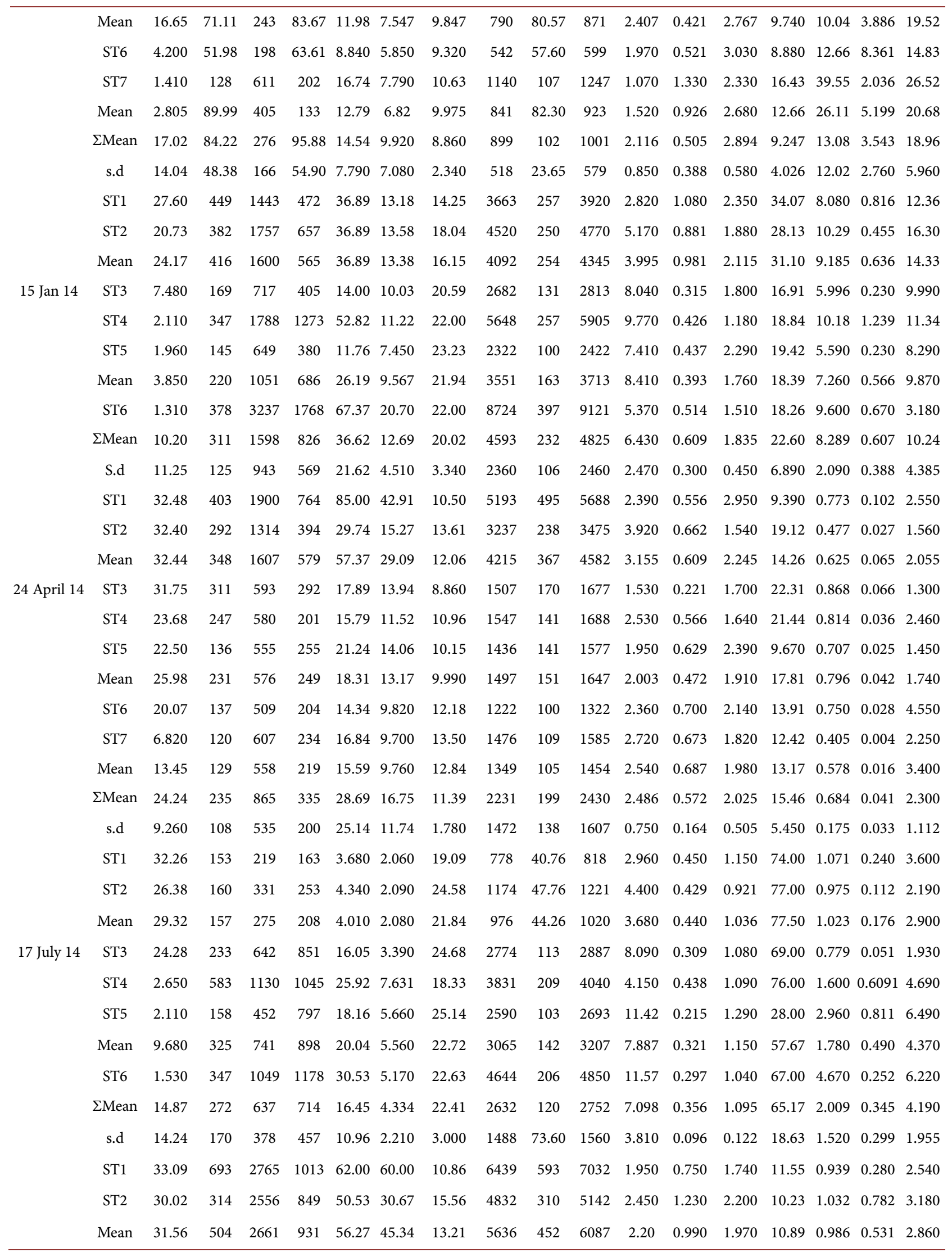




\section{Continued}

\begin{tabular}{|c|c|c|c|c|c|c|c|c|c|c|c|c|c|c|c|c|c|c|}
\hline \multirow[t]{11}{*}{1 Nov 14} & ST3 & 25.67 & 253 & 1371 & 230 & 34.61 & 17.27 & 11.43 & 2445 & 214 & 2659 & 1.720 & 1.330 & 2.440 & 14.65 & 1.420 & 0.259 & 3.850 \\
\hline & ST4 & 14.97 & 742 & 1108 & 525 & 36.84 & 11.15 & 8.280 & 2544 & 307 & 2851 & 1.310 & 0.870 & 2.260 & 66.54 & 1.570 & 0.933 & 2.980 \\
\hline & ST5 & 13.7 & 386 & 1088 & 412 & 35.78 & 14.12 & 13.36 & 2623 & 196 & 2819 & 2.420 & 0.757 & 2.040 & 27.18 & 1.014 & 0.537 & 2.660 \\
\hline & Mean & 18.11 & 460 & 1189 & 389 & 35.74 & 14.18 & 11.02 & 2537 & 239 & 2776 & 1.820 & 0.986 & 2.250 & 36.12 & 1.334 & 0.576 & 3.163 \\
\hline & ST6 & 10.91 & 326 & 1011 & 379 & 37.50 & 14.97 & 10.35 & 2393 & 231 & 2624 & 2.670 & 0.740 & 2.070 & 21.78 & 0.775 & 0.341 & 3.510 \\
\hline & Mean & 7.680 & 398 & 1439 & 589 & 42.37 & 15.82 & 14.87 & 3617 & 241 & 3858 & 3.625 & 0.665 & 2.090 & 24.93 & 0.656 & 0.291 & 2.705 \\
\hline & $\Sigma$ Mean & 18.97 & 454 & 1680 & 601 & 43.50 & 23.55 & 12.74 & 3731 & 300 & 4031 & 2.443 & 0.896 & 2.122 & 25.72 & 1.041 & 0.482 & 2.945 \\
\hline & S.d & 10.69 & 192 & 730 & 288 & 10.20 & 17.23 & 3.730 & 1626 & 136 & 1736 & 1.050 & 0.300 & 0.220 & 19.38 & 0.360 & 0.278 & 0.650 \\
\hline & ST1 & 31.81 & 259 & 397 & 231 & 11.32 & 3.390 & 14.76 & 1101 & 74.62 & 1176 & 4.290 & 0.572 & 1.640 & 76.40 & 1.016 & 0.008 & 1.740 \\
\hline & ST2 & 25.86 & 150 & 281 & 165 & 9.340 & 1.700 & 14.95 & 758 & 50.70 & 809 & 4.310 & 0.600 & 2.180 & 88.20 & 0.400 & 0.004 & 0.920 \\
\hline & Mean & 28.84 & 205 & 339 & 198 & 10.33 & 2.540 & 14.86 & 930 & 62.66 & 993 & 4.300 & 0.586 & 1.910 & 82.30 & 0.708 & 0.006 & 1.330 \\
\hline \multirow[t]{10}{*}{31 Jan 15} & ST3 & 9.520 & 147 & 174 & 133 & 9.210 & 1.330 & 12.56 & 565 & 45.01 & 610 & 2.810 & 0.460 & 2.240 & 111 & 0.394 & 0.023 & 2.050 \\
\hline & ST4 & 7.910 & 219 & 240 & 170 & 11.45 & 2.060 & 14.11 & 850 & 60.22 & 910 & 3.320 & 0.383 & 2.490 & 106 & 2.360 & 0.037 & 2.170 \\
\hline & ST5 & 21.44 & 295 & 350 & 409 & 15.13 & 3.520 & 18.59 & 1631 & 87.74 & 1719 & 5.210 & 0.270 & 1.450 & 83.80 & 0.446 & 0.009 & 1.350 \\
\hline & Mean & 12.96 & 220 & 255 & 237 & 11.93 & 2.303 & 15.09 & 1015 & 64.32 & 1080 & 3.780 & 0.371 & 2.060 & 100 & 1.070 & 0.023 & 1.860 \\
\hline & ST6 & 5.630 & 335 & 561 & 537 & 20.79 & 4.610 & 20.06 & 2309 & 115 & 2424 & 5.190 & 0.307 & 1.290 & 72.67 & 1.520 & 0.008 & 4.090 \\
\hline & ST7 & 1.260 & 656 & 1523 & 793 & 26.32 & 9.700 & 23.84 & 4210 & 177 & 4387 & 4.010 & 0.570 & 1.030 & 67.63 & 1.039 & 0.007 & 1.700 \\
\hline & Mean & 3.450 & 496 & 1042 & 665 & 23.56 & 7.160 & 21.95 & 3260 & 146 & 3406 & 4.600 & 0.440 & 1.160 & 70.15 & 1.280 & 0.008 & 2.890 \\
\hline & $\Sigma$ mean & 14.78 & 294 & 504 & 348 & 14.79 & 3.759 & 16.98 & 1632 & 87.18 & 1719 & 4.163 & 0.452 & 1.760 & 86.53 & 1.025 & 0.013 & 2.003 \\
\hline & s.d & 11.54 & 174 & 466 & 246 & 6.490 & 2.860 & 4.000 & 1284 & 46.25 & 1331 & 0.890 & 0.135 & 0.548 & 16.53 & 0.725 & 0.012 & 1.012 \\
\hline & Kange & 33.09 & 693 & 3237 & 1768 & 85.00 & 60.00 & 22.41 & 8724 & 593 & 9121 & 11.57 & 1.330 & 4.080 & 190 & 39.55 & 8.361 & 27.98 \\
\hline \multirow[t]{2}{*}{ Whole } & Mean & 16.61 & 275 & 761 & 399 & 21.20 & 9.333 & 14.13 & 2168 & 160 & 2328 & 3.650 & 0.622 & 1.662 & 52.99 & 8.504 & 0.781 & 7.564 \\
\hline & s.d & 12.23 & 142 & 510 & 289 & 14.30 & 7.842 & 3.198 & 1346 & 88.66 & 1442 & 1.872 & 0.242 & 0.449 & 21.29 & 4.446 & 1.028 & 3.937 \\
\hline
\end{tabular}

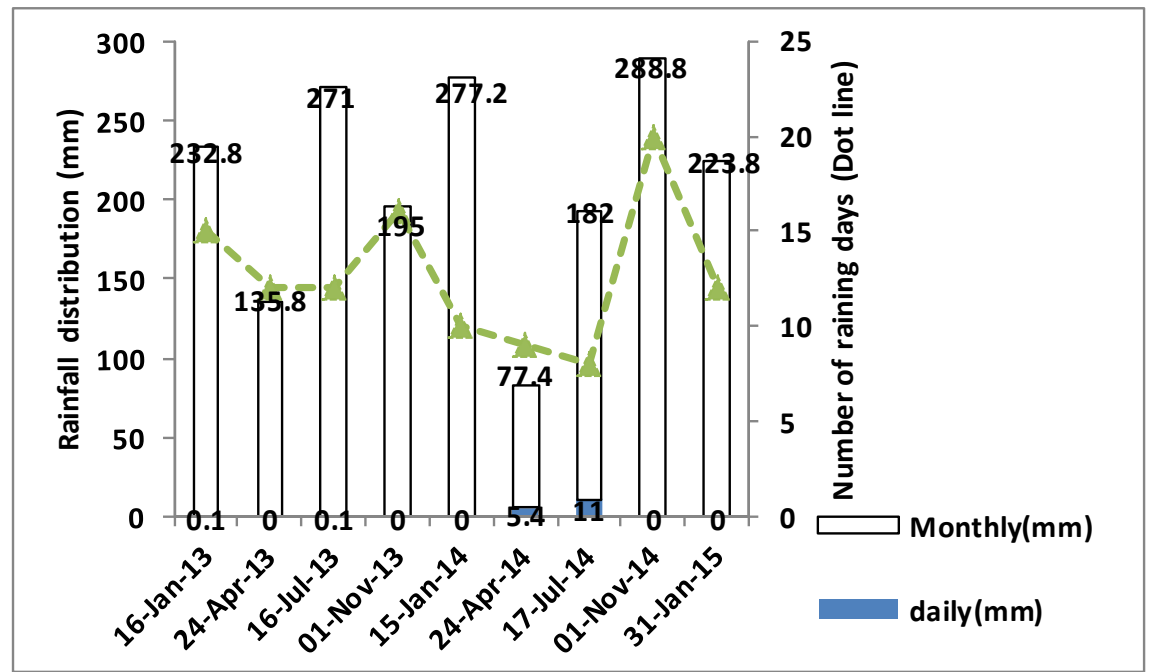

Figure 2. Rainfall distribution data contains monthly, daily and number of raining day adopted from the MMD year 2013 to year 2015 at Kuantan Station. Fortunately on 24 April 2014 and 17 July 2014 have only shown daily rainfall (blue color). 

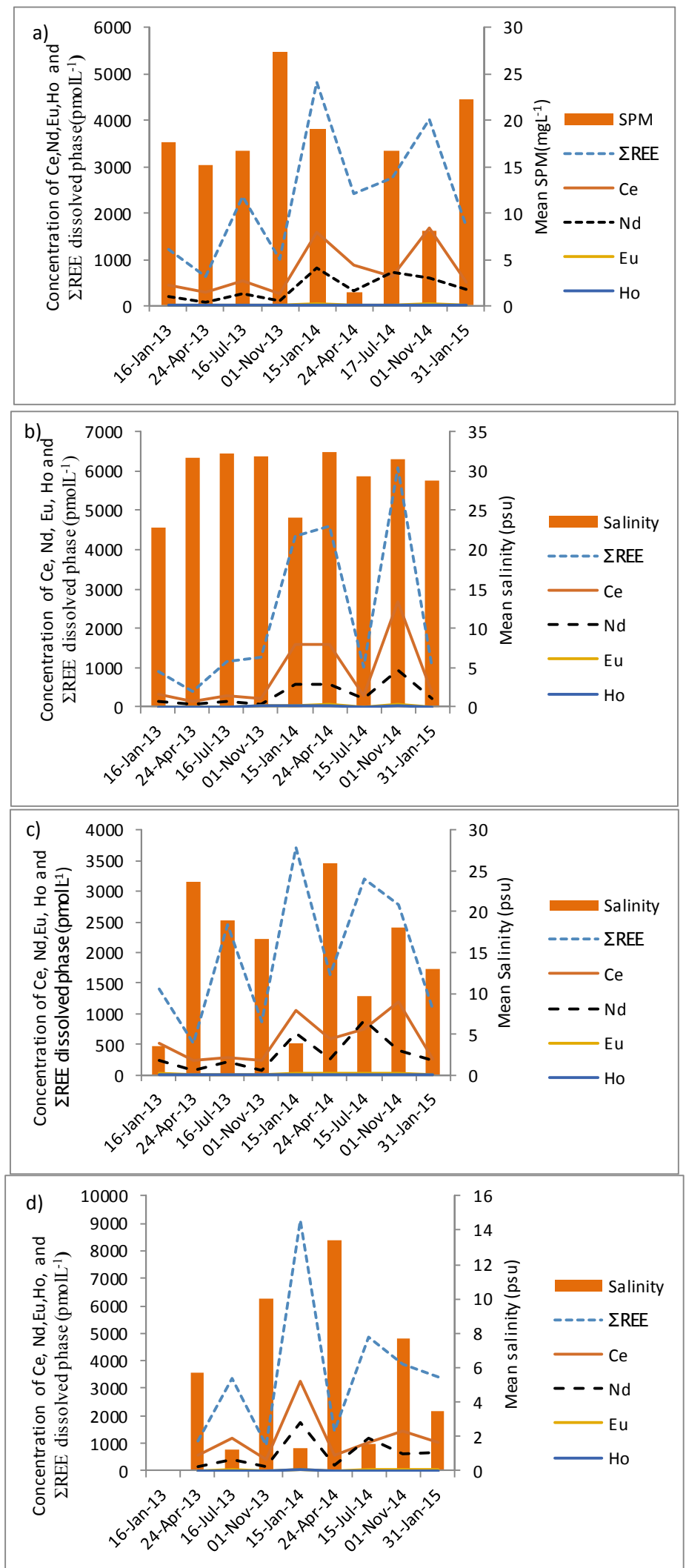

Figure 3. Diagram of relation of mean concentration of $\mathrm{Ce}, \mathrm{Nd}, \mathrm{Eu}, \mathrm{Ho}$ and $\mathrm{REE}$ dissolved toward sampling seasons and (a) mean concentration of SPM, (b) mean salinity in coastal zone, (c) estuarine zone and (d) river zone. 
The same scenarios were also observed by the other elements e.g., Ce, $\mathrm{Nd}, \mathrm{Eu}$ and Ho in the coastal zone especially during monsoon events because of the abundant inorganic carbon in seawater during semidiurnal tides and the tidal pump phenomenon [20]. The river zones occupied by station 2 and station 3 have a water depth of less than $5 \mathrm{~m}$ along the sand bar. Hence, these stations experienced higher deposition of sediments and particles from the sand bar (Figure 1; Table 1). However, the fluctuating rainfall events affected the concentrations of suspended particulate matter in surface river discharges (Figure 3(a)).

According Agaki (2013) [21], it was indicated that the silicate or opal has the potential as an REE scavenger in the seawater column. Notwithstanding the presence of abundant biogenic $\mathrm{SiO}_{2}$ also has a linear relationship with organic matter or organic carbon in the estuarine or marine environment. The distribution of silicate originated from terrestrial sources and detrital minerals from lithogenous and hydrogenous phases [22]. Sungai Balok is surrounded by a mangrove habitat and studies of estuarine fluxes by using REE proxies around the world found that the tropical river flux of trace metals in the dissolved phase have a high possibility of being from rainfall runoff and submarine groundwater discharge [23]. The concentration of biogenic $\mathrm{SiO}_{2}$ from the wet season in January 2014 to dry season during April 2014 and July 2014 (Table 3) found that the high distribution of REEs in January 2014 was associated with the increase of biogenic $\mathrm{SiO}_{2}$. While the decrease of REE concentrations in April 2014 and July 2014 were associated with decreasing biogenic $\mathrm{SiO}_{2}$, which is known as an REE scavenger in the marine environment.

The high ratio value of HREEs in the dissolved phase especially at station ST 1 (Figure 4(h)) might be because of inorganic carbonate from seawater. The inorganic carbonate has been depicted as the greatest positive factor of Tm anomaly (>28) with similar patterns in Figures 4(d)-(f). A positive Gd anomaly in Figure 4(a) \& Figure 4(b) with a range value of lower than 6 also indicated more natural freshwater from the hinterland to the study location [24], and the high positive anomaly value ( $>5$ ) of Pr in Figure 4(d) was due to regenerated particle matter from surface sediments and nutrients [25]. Similarly, researchers have already discussed the enrichment pattern of MREEs and the enrichment pattern of MREE in this sampling locations also showed abundant positive anomaly of Eu (e.g., Figure 4(a); Figure 4(e) and Figure 4(i)) (i.e., [3] [14]).

Table 3. Concentrations level of dissolved biogenic $\mathrm{SiO}_{2}$, (ppm) in Sungai Balok at various times of sampling.

\begin{tabular}{cccc}
\hline \multirow{2}{*}{ Period } & \multicolumn{3}{c}{ Sampling zones } \\
\cline { 2 - 4 } & River & Estuarine & coastal \\
\hline 15-Jan-14 & $5.30 \pm 0.17$ & $5.09^{*}$ & $0.55 \pm 0.06$ \\
24-Apr-14 & $5.16 \pm 0.17$ & $4.95^{*}$ & $0.39 \pm 0.05$ \\
17-Jul-14 & $3.50 \pm 0.48$ & $1.86 \pm 0.23$ & $0.13 \pm 0.03$ \\
\hline
\end{tabular}

$\left.{ }^{*}\right)$ single reading without replicate. 

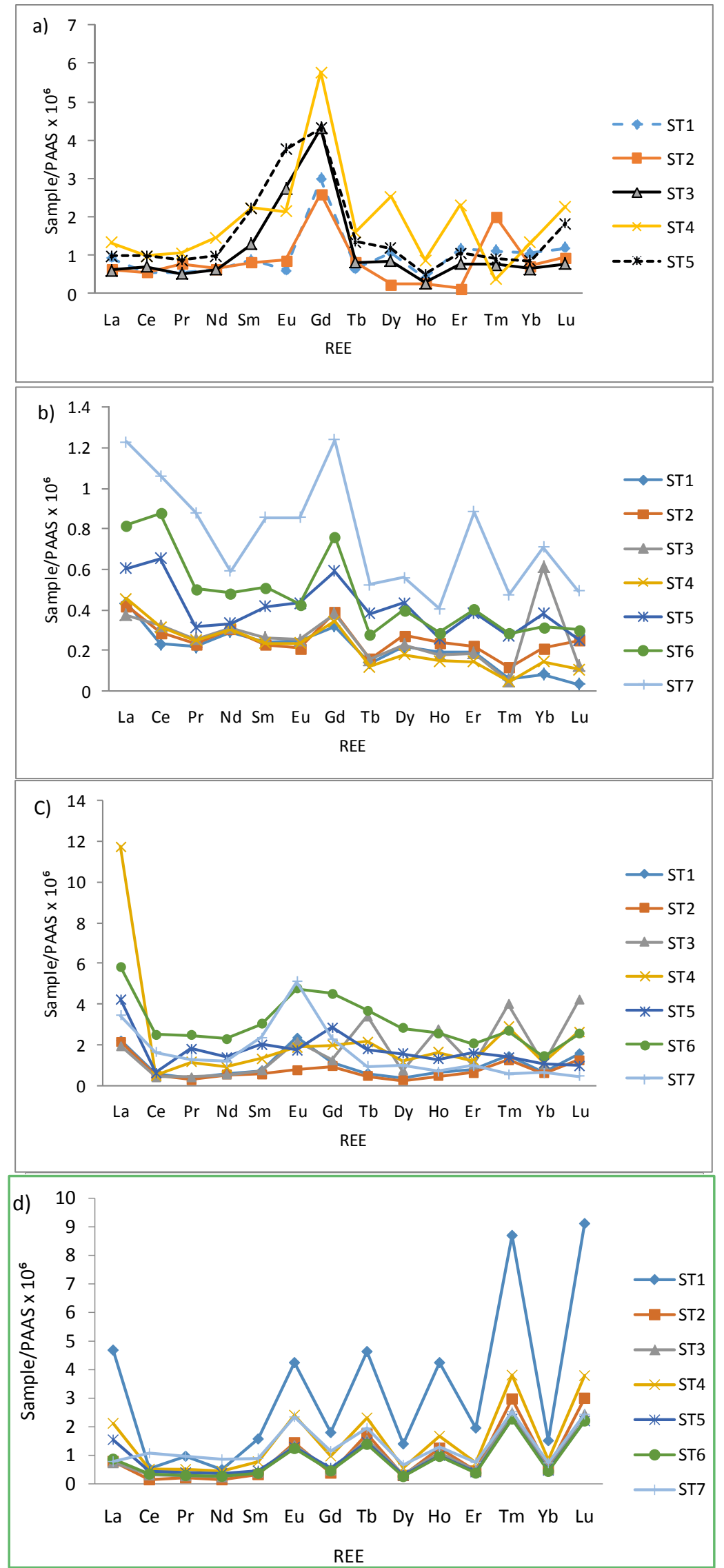

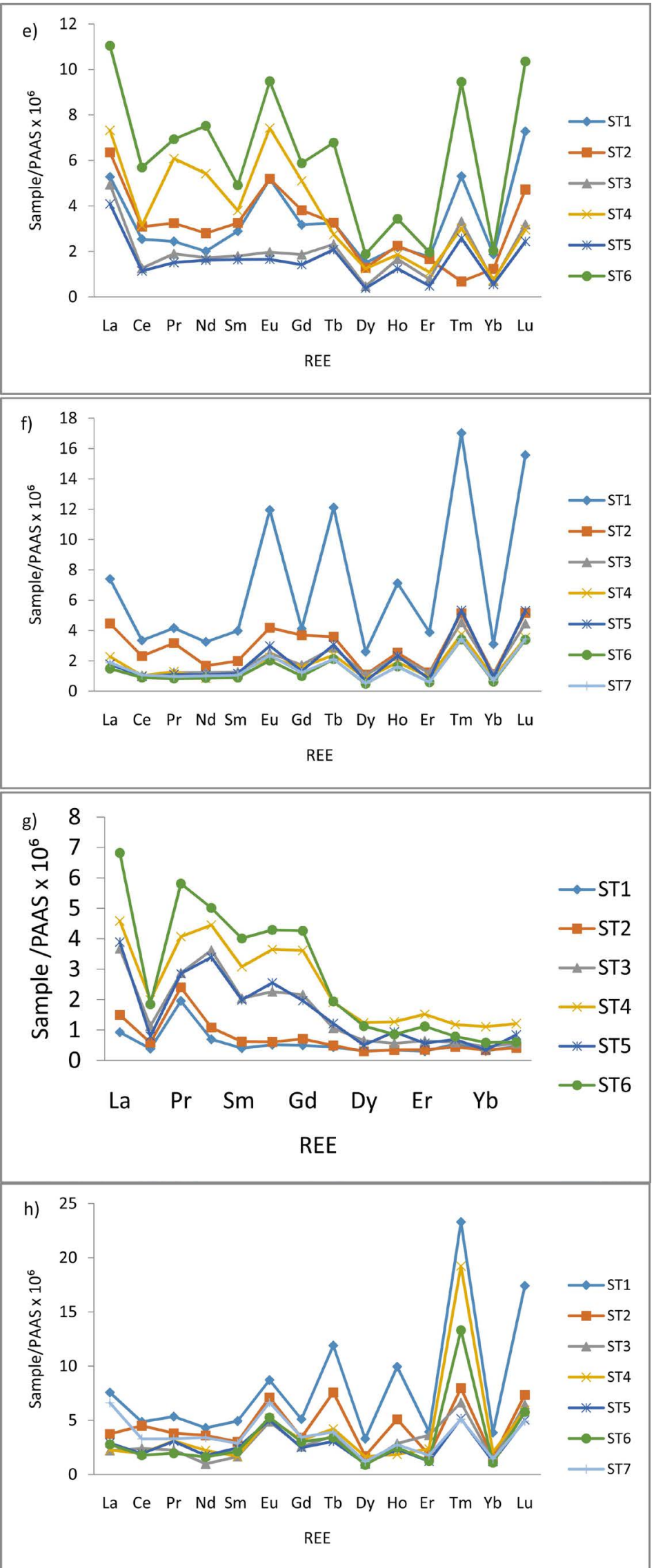


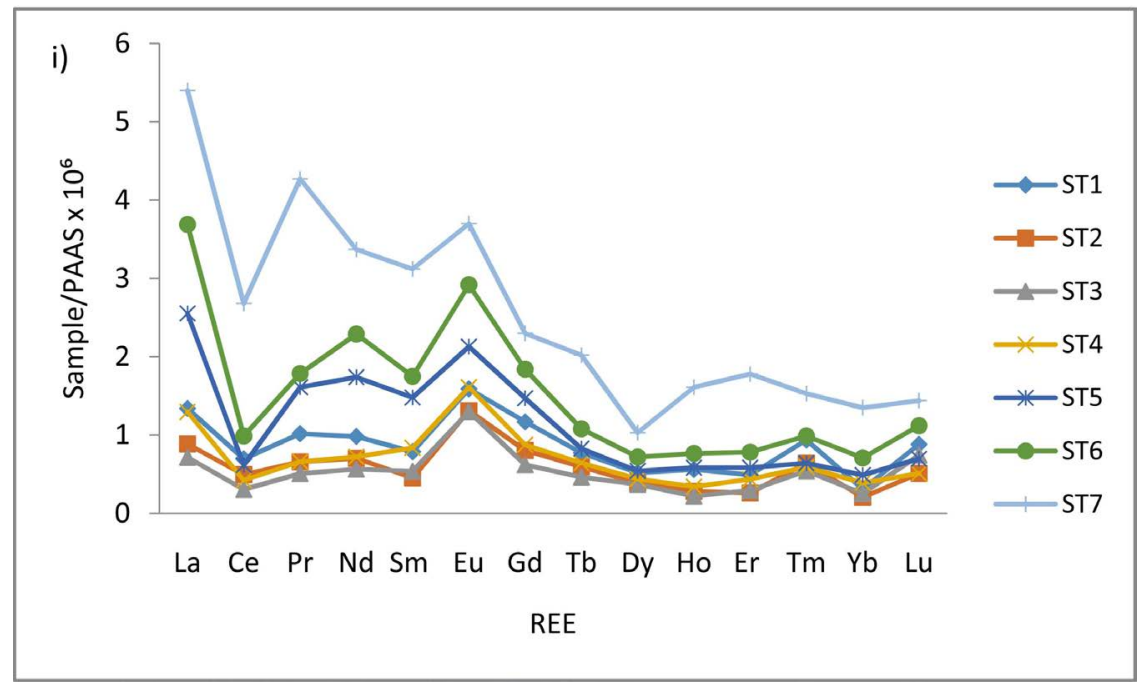

Figure 4. REE normalized PAAS patterns (a) Jan 2013; (b) April 2013; (c) July 2013; (d) Nov 2013; (e) Jan 2014 (f) April 2014; (g) July 2014; (h) Nov 2014; (i) Jan 2015.

\subsection{Terrestrial Input Proxies}

Sungai Balok drains towards the southern South China Sea (sSCS) and the effect of salt water intrusions is higher compared to the west coast of Peninsular Malaysia i.e., the Straits of Malacca [26]. The dissolved REEs have a strong affinity to particulate REEs and reactive particles in the marine environment [1]. Terrestrial runoff occurring during heavy rainfall may have brought an abundance of terrigenous detrital matter and particulate organic matter into the river and ocean environments. The negative statistical correlation was observed between particles and rainwater, which means particles such as dust, particulate matter and volatile gases were scavenged during wet deposition [27].

Ce species is dominant in certain conditions due to abundance among the REEs and in the environment it can be applied to determine the oxidation and reduction stage of cerium either $\mathrm{Ce} / \mathrm{Ce}^{*}<1$ and $\mathrm{Ce} / \mathrm{Ce}^{\star}>1$ by $\mathrm{Ce}^{4+}$ and $\mathrm{Ce}^{3+}$, respectively. The adsorption of dissolved REEs will be scavenged to surface sediments, and the negative $\mathrm{Ce}$ anomaly $\left(\mathrm{Ce} / \mathrm{Ce}^{*}\right)$ along the stations ranging from 0.2 to 1.33 showed that oxidation process of stage IV occurred at Sungai Balok. Researchers Nozaki et al. (1997) [28] and Sholkovitz et al. (1999) [2] also explained the adsorption process could be detected by process of Ce oxidation in the marine environment. However, De Baar (1983) [29] noted that in the presence of oxygen, the seabed regeneration can reduce the Ce (IV) to Ce (III) especially in the river and terrestrial area. Sungai Balok also showed that the positive $\mathrm{Ce} / \mathrm{Ce}^{\star}$ was abundant at the stations in the river and estuarine zones (i.e., ST3 to ST7) ranging from 1.0 to 1.33 . The highest was recorded at ST7 in November 2013 and might be due to the weathering process as shown by lowest ratio value of Y/Ho $(9.247 \pm 4.026)$ and high contents of Mn $\left(3.543 \pm 2.74 \mu \mathrm{mol} \cdot \mathrm{L}^{-1}\right) \mathrm{com}$ pared to other sampling periods. According to Sholkovitz (1992) [4], the increased Mn oxide acts as the catalyst for supplying oxygen demand in surface 
water in order to maintain the dissolved REE in III charge. The moderate and strong significant correlations were determined among $\mathrm{Ce}, \mathrm{Eu}, \mathrm{Nd}$ and $\mathrm{Ho}$, however, strong correlation $(p<0.001)$ was observed between LREE and total REE indicating chemical charge of REE (III) has strong binding affinity among dissolved REE members.

Europium $(\mathrm{Eu})$ is a suitable terrestrial dust proxy available from the lithogenic sources such as igneous, granite rock, dust, hydrothermal and volcanic land (e.g., [4] [14]). The Eu anomaly has the ability to evaluate the lithogenic input through the ratio of $\mathrm{Y} / \mathrm{Ho}[30]$, where the ratio $\mathrm{Y} / \mathrm{Ho}<55$ in the study suggests a lot of freshwater input in the Sungai Balok river system (Figure 5) especially during the Northeast monsoon. The values of Eu anomalies also fluctuated in all the zones ranging 0.489 to 3.3 in the coastal zone, 0.836 to 2.767 in the estuarine zone, and 0.755 to 2.68 in the river zone (Table 2) which might be due to the fluctuation of monsoon events in the sSCS region.

The ratio of $\mathrm{La} / \mathrm{Yb}_{\mathrm{N}}$ is a common indicator to determine the enrichment of LREE over HREE [31] and the ratio was also used as a lithogenic proxy in Tokyo Bay by Takahashi and Noriki (2007) [6]. Meanwhile, the fluctuating rainfall events in the East coast of Peninsular of Malaysia have significant statistical correlation $(p=0.05)$ with $\mathrm{La} / \mathrm{Yb}_{\mathrm{N}}$ ratio and the ratios were high in January 2014 and July 2014 with values of $6.43 \pm 2.47$ and $7.098 \pm 3.81$, respectively. The overall ratios of $\mathrm{La} / \mathrm{Yb}_{\mathrm{N}}$ ranged between 0.69 to 11.57 throughout the sampling periods. The high amount of monthly rainfall distribution in January 2014 increased the soil humidity and dissolution of dissolved REE. Hence, the highest total concentration of $4825 \pm 2460 \mathrm{pmol} \cdot \mathrm{L}^{-1}$ was observed during that time. However, the high ratio of $\mathrm{La} / \mathrm{Yb}_{\mathrm{N}}$ in July 2014 (i.e., lower monthly rainfall) might be due to sudden rainfall during the sampling day along with concentration of $11 \mathrm{~mm}$ per day as reported by MMD (2015) [32] (Figure 2).

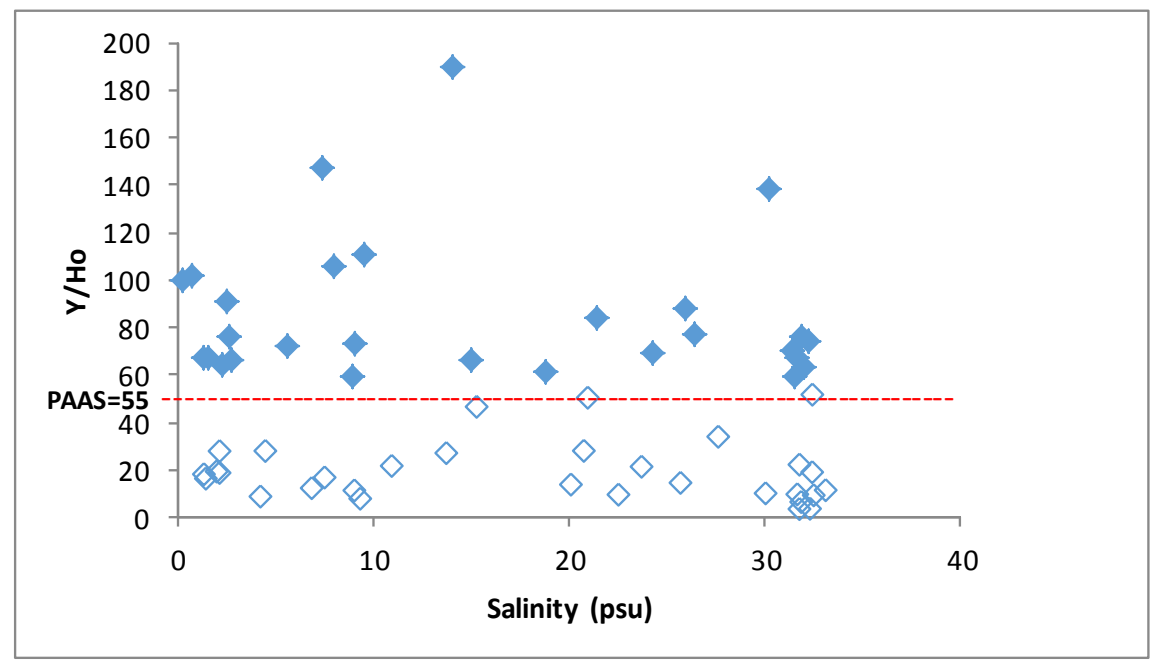

Figure 5. Diagram showing the relationship between dissolved Y/Ho ratio and salinity. Open diamond is below PAAS which distributed from 31 samplings while closed diamond upper that PAAS which distributed from 28 sampling points in the Sungai Balok. 


\subsection{Rare Earth Elements Budget into the Southern South China Sea}

Sungai Balok falls into the southern South China Sea zone [14] and the amount of REEs discharged are still not well documented. Due to the abundance of Ce among REE members, it has been selected for the calculation of river fluxes. The flux of REEs was estimated using formula (1), while an inventory could be developed by formula (2) adopted from the published journal [28]. The inventory and flux of dissolved REEs were estimated using the Ce element in Table 4 and Table 5. By consideration of the residence time of $\mathrm{Ce}$ [33] where the value of $\mathrm{Ce}$ is 80 years while $\mathrm{Nd}$ is 270 years. Due to the unstable nature of $\mathrm{Ce}$, it is not the main choice for the geochemistry scientists to determine the residence time in

Table 4. The inventories of dissolved Ce over three years sampling periods in Sungai Balok.

\begin{tabular}{ccccc}
\hline Date/period & Station & $\begin{array}{c}\text { Average C } \\
\left(\mathrm{pmol} \cdot \mathrm{L}^{-1}\right)\end{array}$ & Average D* $(\mathrm{m})$ & $\begin{array}{c}\text { Inventory } \\
\left(\mathrm{pmol}^{-1} \mathrm{~cm}^{-2}\right)\end{array}$ \\
\hline 16-Jan-13 & St1-St5 & 433 & 3.4 & 147 \\
24-Apr-13 & St1-St7 & 305 & 3.83 & 117 \\
16-Jul-13 & St1-St7 & 549 & 3.83 & 210 \\
1-Nov-13 & St1-St7 & 276 & 3.83 & 106 \\
15-Jan-14 & St1-St6 & 1598 & 3.67 & 387 \\
24-Apr-14 & St1-St7 & 865 & 3.83 & 234 \\
17-Jul-14 & St1-St6 & 637 & 3.67 & 643 \\
1-Nov-14 & St1-St7 & 1680 & 3.83 & 193 \\
31-Jan-15 & St1-St7 & 504 & 3.83 & 331 \\
\hline
\end{tabular}

${ }^{\star} \mathrm{D}$; Average depth stations. Note: Inventory is obtained from Equation (2); The value of L is converted to $\mathrm{cm}^{3}$ and $\mathrm{m}$ is converted to $\mathrm{cm}$, where $1 \mathrm{~L}$ is equals to $1000 \mathrm{~cm}^{3}$ and $1 \mathrm{~m}$ is equals to $100 \mathrm{~cm}$.

Table 5. The dissolved Ce Fluxes over three years sampling periods in Sungai Balok.

\begin{tabular}{ccccc}
\hline Date/period & $\begin{array}{c}c(t i) \text { Average Ce } \\
\left(\mathrm{pmol} \cdot \mathrm{L}^{-1}\right)\end{array}$ & $\begin{array}{c}Q(t i) \text { Average Daily river } \\
\text { discharged } \times 10^{-6} \\
\left(\mathrm{~L} \cdot \mathrm{s}^{-1} \cdot \mathrm{cm}^{-2}\right)\end{array}$ & $\begin{array}{c}\frac{1}{N} \text { Conversion } \\
\text { factor }\left(\mathrm{s} \cdot \mathrm{yr}^{-1}\right)\end{array}$ & $\begin{array}{c}\text { Fluxes } \\
\left(\mathrm{nmol} \cdot \mathrm{cm}^{-2} \cdot \mathrm{yr}^{-1}\right)\end{array}$ \\
\hline $\begin{array}{c}24^{\text {th }} \text { April 2013 to } \\
16^{\text {th }} \text { July 2013 }\end{array}$ & 427 & 6.887 & $84 \times 86,400$ & 21.34 \\
$\begin{array}{l}1^{\text {st }} \text { Nov 2013 to } \\
15^{\text {th }} \text { Jan 2014 }\end{array}$ & 937 & 6.887 & $76 \times 86,400$ & 39.14 \\
$24^{\text {th }}$ April 2014 to & 751 & 6.887 & $85 \times 86,400$ & 37.98 \\
$17^{\text {th }}$ July 2014 & & & & \\
$1^{\text {st }}$ Nov 2014 to \\
$31^{\text {st }}$ Jan 2015 & 1092 & 6.887 & $92 \times 86,400$ & 59.78 \\
\hline
\end{tabular}

Note: Period was divided to two seasons which were during monsoon from November to January while after monsoon from April until July of sampling periods. Average Ce is obtained from average concentration within four months. The conversion factors $1 / N$ of sampling periods are obtained by calculated the days of sampling period time to value 86400 of second per days. Fluxes is obtained from Equation (1) after entering the value of conversion factor, average daily river discharge and dissolved Ce concentration. 
marine, coastal and ocean areas and mostly use the Nd as a proxy. However, from this finding the dissolved REE river flux was identified by measuring the accumulation duration over the sampling period conducted in Table 5, but not the remaining dissolved REE or resident at the sampling point.

$$
\text { Inventory }=C_{\mathrm{REE}} \times D
$$

where, the $C$ is the concentration of dissolved REE $\left(\mathrm{pmol} \cdot \mathrm{L}^{-1}\right)$ in the water column, $D$ is the depth of water column (m). Therefore, an inventory could also be produced by multiplication of the $C$ which is concentration of dissolved REE (pmol. $\mathrm{L}^{-1}$ ) in the water column with $D$ which is the depth of water column (m).

The accumulation of dissolved REEs could be represented by the dissolved $\mathrm{Nd}$ and Eu fluxes with the overall domination during the Northeast monsoon which was also supported by the previous findings in November 1996 [34] and in August 1997 [13]. Although Nd fluxes were widely used to measure the river and seawater fluxes for dissolved REE deposition, the Eu flux could potentially be used to measure the lithogenic input into the river system. According to Nozaki et al. (1999) [28] the South China Sea is the origin of the fluvial and coastal input that has been feeding the Northern South China Sea and also the Sulu Sea at a rate of $1.7 \mathrm{Nd} \mathrm{pmol} \cdot \mathrm{cm}^{2} \cdot \mathrm{yr}^{-1}$, while other $\mathrm{Nd}$ flux contributions were also 3.2 $\mathrm{pmol} \cdot \mathrm{cm}^{-2} \cdot \mathrm{yr}^{-1}$ [5] and $1.2 \mathrm{pmol} \cdot \mathrm{cm}^{-2} \cdot \mathrm{yr}^{-1}$ [35]. Similarly, newer studies on the dissolved Nd flux budget in the Bay of Bengal also reported 1.9 to $6.0 \times 10^{-7}$ $\mathrm{mol} \cdot \mathrm{m}^{-2} \cdot \mathrm{yr}^{-1}$ or 1.9 to $6 \mathrm{mmol} \cdot \mathrm{cm}^{-2} \cdot \mathrm{yr}^{-1}$ caused by high lithogenic input from the Ganges-Brahmaputra river [8].

The calculated inventories of dissolved Ce in January and November 2014 were $586.5 \mathrm{pmol} \cdot \mathrm{cm}^{-2}$ and $643.4 \mathrm{pmol} \cdot \mathrm{cm}^{-2}$, respectively (Table 4). The results from Sungai Balok might be due to the dilution of river water because of frequent heavy rain during the Monsoon and freshwater discharge during weathering processes the in southern South China Sea. Hence, the river flux deposition increased during both periods of November 2013 to January 2014 and November 2014 to January 2015 along the value of $39.14 \mathrm{nmol} \cdot \mathrm{cm}^{-2} \cdot \mathrm{yr}^{-1}$ and 59.78 $\mathrm{nmol} \cdot \mathrm{cm}^{-2} \cdot \mathrm{yr}^{-1}$ (Table 5). Moreover, the inventory of dissolved Ce also showed a strong correlation with monthly rainfall distribution $\left(\mathrm{R}^{2}=0.52\right)$. This statistical correlation showed the possibility of higher rainfall distributions in November until January that might have caused the increased dissolved Ce flux compared to other periods. Overall the dissolved Ce fluxes over seasons as shown in Table 5 were greater compare to previous reports from Nozaki et al. (1999) [28]. The $\mathrm{Nd}$ was used to budget the deposition fluxes in offshore areas and oceans by $\mathrm{Yu}$ et al. (2017) [8] because of the longer residence time in deep locations i.e., it was estimated about 1.5 - 2.6 years. Therefore, it was not practical to state that where the depth of the river is shallower, the residence time is shortest. Furthermore, according to Greaves et al. (1994) [35] the reason to use Nd for estimating flux is because $\mathrm{Nd}$ and $\mathrm{Sm}$ are good indicators for river evolution. However, most of the tropical rivers are still in pristine condition [36], probably due to wash out by a lot of freshwater and abundant of rainfall. This consequently delivered abun- 
dant lithogenic sources especially $\mathrm{Al}$ and $\mathrm{Ce}$ from crustal and most of the Asean continental parts. Despite the unstable Ce element caused by oxidation and reduction, the study has considered to choose it based on the findings of similar river fluxes assessed by Sholkovit et al. (1999) [2] where Eu followed the same behavior of Ce.

According to Sholkovits and Szymczak (2000) [37], the Indonesian archipelagos, Papua New Guinea (PNG), Peninsular Malaysia and Borneo were believed to supply more than $20 \%$ of global sediment input into the sea. The island weathering activities explained that the terrestrial sources draining into rivers and the huge river discharges of more than $2 \times 10^{15} \mathrm{~m}^{3} \cdot \mathrm{s}^{-1}$ fold was due to storms and inundation [2]. The PNG and Indonesia archipelagoes were also fed by sources of volcanic and hydrothermal eruptions. Thus, river input has made the fluvial flux amount increase to $1.4 \times 10^{16} \mathrm{pmol} \cdot \mathrm{yr}^{-1}$ of Eu or estimated to be about $1.4 \times$ $10^{10} \mathrm{pmol} \cdot \mathrm{cm}^{-2} \cdot \mathrm{yr}^{-1}$. These values are greater compared to this present study and might be due to lithogenic and terrigenous volcanic sources around the Indonesian archipelagoes. Furthermore, according to Yu et al. (2017) [8], the amount of fluvial fluxes were also affected by biological uptake from organisms such as plankton, process of iron hydroxide co-precipitation and colloidal coagulation in the marine environment and physical factors such as canyons and tidal changing phenomena. However, the abundance of basaltic and granitic rocks [14] along the East Coast of Peninsular Malaysia should be considered for the increased dissolved Ce Fluxes as well as rainfall events that make Sungai Balok unique.

\section{Conclusion}

The fluctuations of monthly rainfall events directly control the concentration and distribution of REEs in the dissolved phases at sampling locations especially during the Northeast monsoon with the dominant element demonstrated by Ce. The ratio of $\mathrm{La} / \mathrm{Yb}_{\mathrm{N}}$ in the dissolved phase of REEs was also found to be a suitable proxy for evaluating lithogenic sources during rainfall events. The rainwater runoff along lithogenic sources from terrestrial into the river found $\mathrm{Y} / \mathrm{Ho}<55$ that also indicates a large volume of freshwater discharge into the river. The strong significant correlation between $\mathrm{Al}$ and $\mathrm{Fe}$ also supports the lithogenic sources being actively re-suspended in the water column during water mixing due to the rainfall events. Therefore, the river inventories and fluxes could be estimated through the dominated element of $\mathrm{Ce}$, which is related to the high rainfall distribution during the Northeast monsoon. REEs also have the ability to indicate the changes of monsoon seasons and origins of lithogenic sources in rivers through Ce fluxes and $\mathrm{La} / \mathrm{Yb}_{\mathrm{N}}$ ratio.

\section{Acknowledgements}

The authors would like to thank all the members of Marine Chemical Oceanography Laboratory, Faculty of Science and Technology, Universiti Kebangsaan Malaysia for facilitating, helping and assisting during sampling and writing this 
manuscript. Thanks also to the Ministry of Sciences and Technology (MOSTI) for providing a research grant (04-01-02-8F0801).

\section{Conflicts of Interest}

The authors declare no conflicts of interest regarding the publication of this paper.

\section{References}

[1] Daud, Z. and Mohamed, C.A.R. (2016) A Short Review of the Distribution and Behavior of Rare Earth Elements in the South China Sea. Pollution Research, 35, 25-36.

[2] Sholkovitz, E.R., Elderfield, H., Szymczak, R. and Casey, K. (1999) Island Weathering: River Sources of Rare Earth Elements to the Western Pacific Ocean. Marine Chemistry, 68, 39-57. https://doi.org/10.1016/S0304-4203(99)00064-X

[3] Shynu, R.V., Rao, P., Pratima, M., Kessarkar and Rao, T.G. (2011) Rare Earth Elements in Suspended and Bottom Sediments of the Mandovi Estuary, Central West Coast of India: Influence of Mining. Estuarine, Coastal and Shelf Science, 94, 355-368. https://doi.org/10.1016/j.ecss.2011.07.013

[4] Sholkovitz, E.R. (1992) Chemical Evaluation of Rare Earth Elements Fractionation between Colloidal and Solution Phases of Filtered River Water. Earth and Planetary Science Letter, 114, 77-84. https://doi.org/10.1016/0012-821X(92)90152-L

[5] Goldstien, S.J. and Jacobsen, S.B. (1988) Rare Earth Element in River Water. Earth and Planetary Science Letters, 89, 35-47. https://doi.org/10.1016/0012-821X(88)90031-3

[6] Takahashi, N. and Noriki, S. (2007) Rare Earth Elements and Opal/CaCO $\mathrm{Catio} \mathrm{of}_{3}$ Ration Sinking Particles Observed with a Time-Series Sediment Trap at the Mouth of Tokyo Bay. Journal of Oceanography, 63, 941-951. https://doi.org/10.1007/s10872-007-0079-5

[7] Censi, P., Sprovieri, M., Saiano, F., Di Geronimo, S.I., Larocca, D. and Placenti (2007) The Behavior of REEs in Thailand's Mae Klong Estuary: Suggestions from the Y/Ho Ratios and Lanthanidae Tetrad Effects. Estuarine, Coastal and Shelf Science, 71, 569-579. https://doi.org/10.1016/j.ecss.2006.09.003

[8] Yu, Z., Colin, C., Douville, E., Meynadier, L. and Bassinot, F. (2017) Seasonal Variations in Dissolved $\varepsilon \mathrm{Nd}$ in the Bay of Bengal. Earth and Planetary Sciences Letters, 479, 310-321. https://doi.org/10.1016/j.epsl.2017.09.022

[9] Zhu, Z., Liu, C.-Q., Wang, Z.-L., Liu, X. and Li, J. (2016) Rare Earth Elements Concentrations and Speciation in Rainwater from Guiyang and Acid Rain Impacted Zone of Southwest China. Chemical Geology, 44, 23-34.

https://doi.org/10.1016/j.chemgeo.2016.08.038

[10] Ng, S.W.P., Chung, S.L., Robb, L.J., Searle, M.P., Ghani, A.A., Whitehouse, M.J., Oliver, G.J.H., Sone, M., Gardiner, M.J. and Roselee, M.H. (2015) Petrogenesis of Malaysia Granitoids in the Southern Asian Tin Belt. Part 1. Geochemical and Sr-Nd Isotopes Characteristics. Geological Society of American Bulletin, 127, 1209-1237.

[11] Thompson, A., Amistadi, M.K., Chadwick, O.A. and Chorover, J. (2013) Fractionation of Yttrium and Holmium during Basaltic Soil Weathering. Geochemica at Cosmochimica Acta, 119, 18-30. https://doi.org/10.1016/j.gca.2013.06.003

[12] Smith, N.P. (1993) Tidal and Non-Tidal Flushing o Florida Indian Lagoon. Estuaries, 16, 739-746. https://doi.org/10.2307/1352432 
[13] Yu, Z., Colin, C., Douville, E., Meynadier, L., Duchamp-Alphonso, S., Sepulcre, S., Wan, S., Song, L., Wu, Q., Xu, Z. and Bassinot, F. (2017) Yttrium and Rare Earth Element Partitioning in Seawater from the Bay of Bengal. Geochemistry, Geophysics, Geosystems, 18, 1388-1403. https://doi.org/10.1002/2016GC006749

[14] Sultan, K. and Shazili, N.A.M. (2009) Rare Earth Element in Tropical Water, Soil and Sediment of Terengganu River Basin, Malaysia. Journal of Rare Earth, 27, 1072-1078. https://doi.org/10.1016/S1002-0721(08)60391-9

[15] Bourg, A.C.M. (1983) Role of Freshwater or Seawater Mixing on Trace Metal Adsorption Phenomenon. In: Wong, C.S., Boyle, E., Bruland, K.W. and Burton, J.D., Eds., Trace Metal in Sea Water, Plenum, New York, 195-208. https://doi.org/10.1007/978-1-4757-6864-0_12

[16] Coradin, T., Eglin, D. and Livage, J. (2004) The Silicomolybdic Acid Spectrometric Method and Its Application to Silicate/Biopolymer Interactions Studies. Spectroscopy, 18, 567-576. https://doi.org/10.1155/2004/356207

[17] Benning, R., Schua and Feger, K. (2012) Fluxes of Nitrogen, Phosporus and Dissolved Organic Carbon in the Inflow of the Lehnmuhle Reservoir (Saxony) as Compared to the Streams Draining Three Main Land-Use Types in the Catchman. Advance in Geosciences, 32, 1-7. https://doi.org/10.5194/adgeo-32-1-2012

[18] Department of Irrigation and Drainage (DID) (2011) Review of the National Water Resources Study (2000-2050) and Formulation of National Water Resources Policy. Final Report 12, 444.

[19] McLennan, S.M. (1989) Rare Earth Elements in Sedimentary Rocks: Influences of Provenance and Sedimentary Process. The Mineralogy Society of America, 21, 169-200. https://doi.org/10.1515/9781501509032-010

[20] Wolanski, E., Williams, D. and Hanert, E. (2006) The Sediment Trapping Efficiency of the Micro-Tidal Daly Estuary, Tropical Australia. Estuarine, Coastal and Shelf Science, 69, 291-298. https://doi.org/10.1016/j.ecss.2006.04.023

[21] Agaki, T. (2013) Rare Earth Elements (REE)-Silicic Acid Complexes in Seawater to Explain the Incorporation of REEs in Opal and the Leftover REEs in Surface. New Interpretation of Dissolved REE Profiles. Geochimica et Cosmochimica Acta, 113, 174-192. https://doi.org/10.1016/j.gca.2013.03.014

[22] Tanaka, K., Akagawa, F., Yamamoto, K., Tani, Y., Kawabe, I. and Kawai, T. (2007) Rare Earth Element of Lake Baikal Sediment: Its Implication for Geochemical Response Climate to Climate Change during Last Glacial/Interglacial Transition. Quaternary Sciences Reviews, 26, 1362-1368. https://doi.org/10.1016/j.quascirev.2007.02.004

[23] Johannesson, K.H. and Burdige, D.J. (2007) Balancing the Global Oceanic Neodymium Budget: Evaluating the Role of Groundwater. Earth and Planetary Sciences Letter, 253, 129-142. https://doi.org/10.1016/j.epsl.2006.10.021

[24] Kulaksiz, S. and Bau, M. (2007) Contrasting Behavior of Anthropogenic Gadolinium and Natural Rare Earth Elements in Estuaries and the Gadolinium Input into the North Sea. Earth and Planetary Sciences Letters, 260, 361-371. https://doi.org/10.1016/j.epsl.2007.06.016

[25] Lerche, D. and Nozaki, Y. (1998) Rare Earth Elements of Sinking Particulate Matter in Japan Trench. Earth and Planetary Science Letters, 159, 71-86. https://doi.org/10.1016/S0012-821X(98)00066-1

[26] Bujang Saili, N.A. and Mohamed, C.A.R. (2014) Behavior of ${ }^{210} \mathrm{Po}$ and ${ }^{210} \mathrm{~Pb}$ in Shallow Water Region of Mersing Estuary, Johor, Malaysia. Environment Asia, 7, 7-18.

[27] Ambe, Y. and Nishikawa, M. (1987) Variations in Different-Sized Water-Insoluble 
Particulate Matter in Rainwater. Atmosphere Environment, 21, 1469-1471. https://doi.org/10.1016/0004-6981(67)90095-9

[28] Nozaki, Y., Alibo, D.S., Amakawa, H., Gamo, T. and Hasumoto, H. (1999) Dissolved Rare Earth Elements and Hydrography in the Sulu Sea. Geochimica et Cosmochimica Acta, 57, 2171-2181. https://doi.org/10.1016/S0016-7037(99)00142-8

[29] De Baar, H.J.W. (1983) Marine Geochemistry on REE. PhD Thesis, MIT University, Boston.

[30] Cidu, R., Antisari, L.V., Biddau, R., Buscaroli, A., Carbone, S., Da Pelo, S., Dinelli, E., Vianello, G. and Zannoni, D. (2013) Dynamics of Rare Earth Elements in Water-Soil System: The Case Study of the Pineta San Vitale (Ravenna, Italy). Geoderma, 193-194, 52-67. https://doi.org/10.1016/j.geoderma.2012.10.009

[31] Han, Z., Xu, Z., Tang, Y. and Zhang, G. (2009) Rare Earth Element Patterns in the Karst Terrain of Guizhou Province, China: Implication for Water/Particle Interaction. Aquatic Geochemistry, 15, 457-484.

https://doi.org/10.1007/s10498-009-9061-8

[32] Malaysian Meteorological Department (MMD) (2015) Rekod Data Meteorologi di Stesen Meteorologi Kuantan dari Januari 2013 hingga Januari 2015 (In-Bahasa Malaysia).

[33] Goldberg, E.D., Koide, M., Schmitt, R.A. and Smith, R.H. (1963) Rare Earth Distributions in the Marine Environment. Journal of Geophysical Research, 68, 4209-4217. https://doi.org/10.1029/JZ068i014p04209

[34] Nozaki, Y., Lerche, D., Alibo, D.S. and Snidvongs, A. (2000) The Estuarine Geochemistry of Rare Earth Elements and Indium in the Chao Phraya River, Thailand. Geochimica et Cosmochimica Acta, 64, 3983-3994. https://doi.org/10.1016/S0016-7037(00)00473-7

[35] Greaves, M.J., Statham, P.J. and Elderfield, H. (1994) Rare Earth Element Mobilization from Marine Atmospheric Dust to Seawater. Marine Chemistry, 46, 255-260. https://doi.org/10.1016/0304-4203(94)90081-7

[36] Bau, M., Möller, P. and Dulski, P. (1997) Yttrium and Lanthanides in Eastern Mediterranean Seawater and Their Fractionation during Redox-Cycling. Marine Chemistry, 56, 123-131. https://doi.org/10.1016/S0304-4203(96)00091-6

[37] Sholkovits, E.R. and Szymczak, R. (2000) The Estuarine Geochemistry of Rare Earth Element; Comparison of the Amazon, Fly Sepik and the Gulf of Papua System. Earth and Planetary Science Letters, 179, 299-309. https://doi.org/10.1016/S0012-821X(00)00112-6 